\title{
PRESENCE OF HISTAMINE AND PHYSICAL HAZARD ON DRIED ANCHOVY (Stolephorus spp.) LOCALLY PRODUCED AND MARKETED IN THE ISLAND PROVINCE OF MARINDUQUE, PHILIPPINES
}

\author{
Wilfredo Q. Villavicencio, Jr. \\ Faculty, Department of Fisheries, Marinduque State College
}

Article DOI: https://doi.org/10.36713/epra9347

DOI No: 10.36713/epra9347

\begin{abstract}
This research work aimed to investigate the presence of histamine and physical hazard on dried anchovy samples. Seventytwo kilograms of dried anchovy samples were collected at random from various local producers and retailers in Marinduque, Philippines, and tested for the occurrence of histamine and physical hazard. Dried anchovy samples from various producers and retailers have histamine levels ranging from $26.90 \mathrm{mg} / \mathrm{kg}$ to $2218.50 \mathrm{mg} / \mathrm{kg}$ and $34.40 \mathrm{mg} / \mathrm{kg} \mathrm{to} 1992.10 \mathrm{mg} / \mathrm{kg}$, respectively. All dried anchovy samples had a total of 367 grams of accumulated physical hazard, such as gravels, feathers, tiny debris, plastics, shells, and broken glasses. The highest mean value of histamine was observed in producers (625.472 \pm 117.335); however, the Mann-Whitney test revealed no significant difference $(p>0.05)$ between producers and retailers. Most dried anchovy samples collected from producers and retailers $(58.33 \%)$ met the standard limit of $200 \mathrm{mg} / \mathrm{kg}$ (CODEX standard for fish and fishery products), but thirty of them (41.67\%) exceeded the standard limit. As a result, these findings will be used to improve existing dried anchovy processing technology, making it more competitive and ensuring consumer safety.
\end{abstract}

KEYWORDS - histamine, dried anchovy, physical hazard

\section{INTRODUCTION}

Dried anchovy is an important process fishery product in the Philippines and is consumed widely, locally and abroad. This product is rich in omega-3 fatty acids that lower the levels of triglycerides and cholesterol in the blood and at the same time an excellent source of protein and other minerals such as calcium and selenium ("The Pharmaceutical Journal", 2009, par, 2). Despite the popularity of dried anchovy, this important commodity is often prepared in an unhygienic condition that may cause a possible negative effect on consumers (Sumitha, Sundar \& Halady Shetty, 2014 as cited by Amascual et al, 2020).

In Marinduque, the production of dried anchovy is very evident, especially during peak season. Around 2,000 to 5,000 kilograms of dried anchovy are produced every year (as personal communication with local producers) and sold within and outside the province. However, as a result of the high demand for this commodity and the rapid increase in production, the quality of dried anchovy has deteriorated, with some contributing factors including poor sanitation, mishandling and improper storage of raw materials, and cross-contamination.

Consumption of spoiled or bacterially contaminated fish exposes you to histamine, a foodborne chemical hazard (Semora et al, 2016). Histamine fish poisoning is the most common biogenic amine-related to food poisoning and has been linked to a variety of incidents (Hungerford, 2010) and has also been utilized as a quality and safety indicator in fish and fishery products (Prester, 2011; Visciano et al., 2012).

Incidents of histamine poisoning were recorded and observed among seven male employees of the Ninoy Aquino International Airport after eating "tambakol" (Thunnus albacores). Dizziness, palpitations, flushing, dyspnea, headache, perioral numbness, urticarial rashes, pruritus, and paresthesias of the hands were among the symptoms experienced by those who were exposed. They were given oral antihistamines at first and then referred to a local hospital for additional treatment. The leftover fish tested positive for $30 \mathrm{mg}$ histamine $/ 100 \mathrm{~g}$ flesh (standard limit: $200.0 \mathrm{mg} / \mathrm{kg}$ meat) by the Bureau of Fisheries and Aquatic Resources (BFAR), confirming the diagnosis of scombroid fish poisoning (Noche R. et al., 1998).

In addition, the presence of physical hazards on dried fishery products such as stone, broken glasses, wood, bones, shells, etc. is also considered a serious threat to consumers. Choking, injury, including laceration and perforation of tissues in the mouth, throat, stomach, or intestines, are all potential risks of physical hazards. Broken teeth and gum damage may also be the result (Olsen, 1998). The Bureau of Food and Drugs in the Philippines has set a regulation limit of $200.0 \mathrm{mg} / \mathrm{kg}$ for histamine in salted-dried fish products (BFAD-PNS, 2006). The Food Safety Act of 2013 strengthens the country's food safety regulatory system by safeguarding the public from foodborne and water-borne illnesses and unsanitary, unwholesome, misbranded, or adulterated goods (Joint DADOH Administrative Order No. 2015-0007). As a result, it's critical to develop a profile of histamine in dried anchovy products that may be used as a benchmark for improving drying technologies in Marinduque and the rest of the country.

\section{OBJECTIVES}

This research work aimed to investigate the level of histamine and classify the physical hazard present on dried anchovy samples which are needed to craft possible 
recommendations to ensure the quality and safety of the consumers.

\section{METHODOLOGY}

Materials

A total of 72 kilograms of dried anchovy samples were randomly collected from different local producers and retailers in Marinduque Philippines from April to June 2021. All samples were packed aseptically using food-grade plastic and sealed using a vacuum sealer to avoid cross-contamination during storage. The dried anchovy samples were coded and labeled to circumvent mistakes during analysis. All the samples were kept at room temperature.

\section{Determination of Histamine Content}

A rapid ELISA method of analysis was conducted to determine the histamine content of dried anchovy samples using Veratox Histamine Total Quantitative Test Kit (AOAC Research Institute Validated: Certificate No. 070703) with three trials. The analysis was conducted at Marinduque State College Food/Fish Processing Center located at Banuyo, Gasan, Marinduque. The detailed procedure is stated below:

\section{B.1 Preparation of Sample and Extraction}

Using a mortar and pestle, 10 grams of anchovy sample were ground and homogenized, and the homogenized and powdered sample was then added to $90 \mathrm{~mL}$ distilled water in a clean plastic extraction bottle. To suspend the fish tissue in the water, the bottle was tightly sealed and forcefully agitated for 15 to 20 seconds. After 5 minutes, shake the bottle for 15 to 20 seconds to re-suspend the fish tissue, then wait 5 minutes and shake the bottle for 15 to 20 seconds to re-suspend the fish tissue once again. For around 30 seconds, the fish tissue was allowed to settle to the bottom of the bottle. A syringe filter was used to filter the extracted anchovy sample into a clean container.

\section{B.2 Sample Extract Dilution}

Using a clean pipette tip, $100 \mathrm{uL}$ of dried anchovies sample extract was added to $10 \mathrm{~mL}$ of sample extract diluent buffer in a clean test tube and gently swirled to mix. The dried anchovy extract sample had already been diluted and was ready to be tested.

\section{B.3 Assay Proper}

Before the assay, all of the chemicals were set to bring at room temperature and mixed by swirling the bottle. $100 \mu \mathrm{L}$ of the conjugate was added to each read-marked mixing well, and $100 \mu \mathrm{L}$ of controls and diluted anchovy sample extract was transferred to each re-marked mixing well using a new pipette tip. Using a 12 channel pipettor, pipette the liquids up and down 3 to 5 times in the mixing well. After completely mixing the liquids, transfer $100 \mu \mathrm{L}$ to the antibody-coated wells and incubate for 10 minutes at room temperature; discard the red-marked mi fing wells. Air bubbles should be removed from the bottom of the wells with a dry cloth or towel to avoid errors during analysis. Using Neogen's ELISA reader, read the result while accounting for the dilution factor based on the table above. After adding the red stop solution, the results should be read within 20 minutes.

\section{Determination of Physical Hazard}

Physical hazards found on dried anchovy samples were gathered and grouped into the following categories (broken glasses, stone, wood, plastic, shells, feathers, etc.). A digital weighing scale and a caliper were used to determine the weight and size of the identified physical hazards. A Microsoft Excel spreadsheet was used to record and tabulate the data.

\section{STATISTICS}

Independent Sample T-test was used to determine the significant difference between dried anchovy samples collected from producers and retailers in terms of histamine content and expressed as mean \pm standard error using JASP 0.14.1.0. (JASP Team, 2020). Before the T-test, data were checked to follow parametric assumptions such as homogeneity of variance, normality of data, and outliers. However, if the data failed to meet the parametric assumption, the non- parametric MannWhitney test was used. A value of $p<0.05$ was used to indicate a significant deviation.

\section{RESULTS AND DISCUSSION}

The goal of this study is to look at the level of histamine in dried anchovy samples collected from local producers and retailers in Marinduque, Philippines, as well as the presence of physical hazards.

Histamine is one of the most serious food safety problems. Ingesting large amounts of histamine can have significant health impacts, such as headaches, dizziness, nausea, vomiting, and urticarial reactions (Connell 1980 as cited by Peralta, 2003 and Villavicencio, 2018)

The histamine profile of dried anchovy samples is shown in Table 1. Based on the analysis conducted, the histamine content of dried anchovy samples from producers and retailers ranges from $29.90 \mathrm{mg} / \mathrm{kg}$ to $2218.50 \mathrm{mg} / \mathrm{kg}$ and $34.40 \mathrm{mg} / \mathrm{kg}$ to $1992.10 \mathrm{mg} / \mathrm{kg}$ respectively. This finding is almost similar to the previously reported data of Amascual, et al., (2020) in driedsalted fish in the local supermarket of Samar with histamine content ranging from $73.27 \mathrm{mg} / \mathrm{kg}$ to $>1500 \mathrm{mg} / \mathrm{kg}$

Table 1. The histamine profile of dried anchovy samples collected from producers and retailers in Marinduque, Philippines

\begin{tabular}{|l|c|c|c|c|c|c|}
\hline Source & $\begin{array}{c}\text { No. of } \\
\text { Samples }\end{array}$ & Mean & SE & Median & Min. & Max. \\
\hline Retailer & 36 & 496.34 & 106.79 & 133.80 & 34.40 & 1992.10 \\
\hline Producer & 36 & 625.37 & 117.34 & 174.18 & 29.90 & 2218.50 \\
\hline
\end{tabular}

Figure 1 also shows the overall histamine content of dried anchovy. The highest maximum value of histamine was found from producers who affect data normality, inhibiting the application of the parametric test. The sample medians $\left(\mathrm{x}^{2}=\right.$ $750.50, \mathrm{p}=0.251)$ demonstrated no significant difference $(\mathrm{p}>$ 0.05 ) between producers and retailers, according to the MannWhitney test. These data suggest that dried anchovy samples acquired from both sources were of equal quality and safety. Furthermore, the elevated histamine level reported on anchovy samples could be due to inadequate storage and manufacturing practices utilized in the production of dried anchovy.

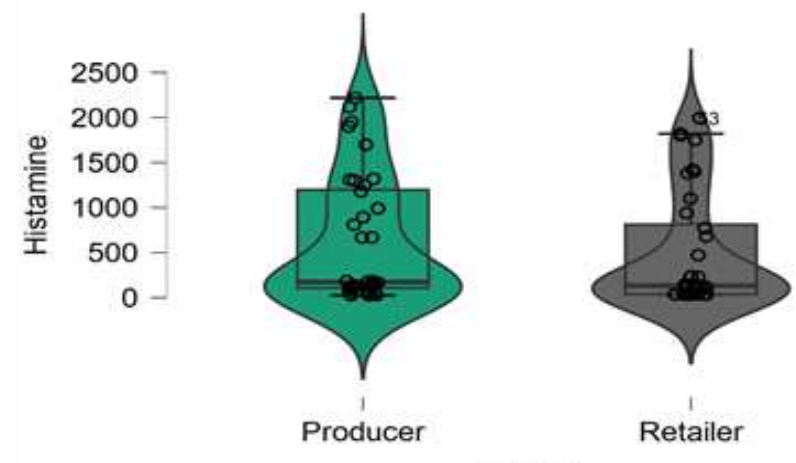

Source

Figure 1. The overall histamine content of dried anchovy samples collected from producers and retailers in Marinduque, Philippines

Table 2 shows the distribution of histamine content in all dried anchovies samples, with $42(58.33 \%)$ of them meeting the standard limit of $200 \mathrm{mg} / \mathrm{kg}$ (Philippine National Standard for Dried Anchovies), and three $(4.17 \%)$ of them exceeding the 
standard limit. Similarly, $27(37.5 \%)$ anchovy samples from producers and retailers had a concentration of more than 500 $\mathrm{mg} / \mathrm{kg}$, which could be dangerous and unfit for human consumption. (Zaman et al., 2010). Simora and Peralta (2018) found that $76.2 \%$ of traditional dried fishes in the Philippines, including anchovies, exceeded the US Food and Drug Administration standard of $5 \mathrm{mg} .100 \mathrm{~g}-1$, which confirms the findings of this study. These findings imply that following appropriate manufacturing and sanitation practices while producing dried anchovy could be a viable solution for ensuring safety and quality.

Table 2. Distribution of histamine content in 72 dried anchovy samples locally produced and distributed in Marinduque, Philippines

\begin{tabular}{|c|c|c|c|c|}
\hline $\begin{array}{c}\text { Histamin } \\
\text { e Content } \\
\text { (mg/kg) }\end{array}$ & \multicolumn{2}{|c|}{ Producer } & \multicolumn{2}{c|}{ Retailer } \\
\cline { 2 - 5 } & $\begin{array}{c}\text { Frequenc } \\
\mathbf{8}\end{array}$ & $\begin{array}{c}\text { Percentag } \\
\mathbf{e}\end{array}$ & $\begin{array}{c}\text { Frequenc } \\
\mathbf{y}\end{array}$ & $\begin{array}{c}\text { Percentag } \\
\mathbf{e}\end{array}$ \\
\hline 31 to 200 & 18 & 8.33 & 0 & 0.00 \\
\hline $\begin{array}{c}201 \text { to } \\
400\end{array}$ & 0 & 0.00 & 3 & 8.33 \\
\hline $\begin{array}{c}401 \text { to } \\
600\end{array}$ & 0 & 0.00 & 1 & 7.78 \\
\hline $\begin{array}{c}601 \text { to } \\
800\end{array}$ & 2 & 5.56 & 2 & 6.56 \\
\hline $\begin{array}{c}801 \text { to } \\
1000\end{array}$ & 3 & 8.33 & 1 & 2.78 \\
\hline$>1001$ & 10 & 27.78 & 8 & 22.22 \\
\hline Total & 36 & 100.00 & 36 & 100.00 \\
\hline
\end{tabular}

Physical hazards such as stone, broken glasses, wood, bones, shells, and other physical hazards on dried fishery products are also considered a major threat to consumers. Physical hazards on dried anchovy samples were also determined in this study. The weight of accumulated physical hazards acquired from producers was $244 \pm 1.98$ grams, while the weight collected from retailers was $123 \pm 2.15$ grams, with sizes of $12.67 \pm 1.98$ millimeters and $16.83 \pm 2.52$ millimeters, respectively (see Table 3). Foreign objects with maximum dimensions of less than $7 \mathrm{~mm}$ rarely cause trauma or serious injury, according to the FDA Health Hazard Board, except in certain risk groups such as infants, the elderly, or surgical patients (Olsen, 1998). Foreign matter on dried anchovy products, according to the Philippine National Standard for Dried Anchovy, shows non- compliance with acceptable manufacturing and sanitary practices; hence, enhancing dried anchovy processing technology is critical to assure customer quality and safety.

Table 3. The weight, size and classification of physical hazard identified in the dried anchovy samples.

\begin{tabular}{|c|l|l|l|l|}
\hline Source & $\begin{array}{c}\text { No. of } \\
\text { Samples }\end{array}$ & $\begin{array}{c}\text { Weight } \\
\text { (g) }\end{array}$ & Size (mm) & Classification \\
\hline Retailer & 36 & $124 \pm 2.15$ & $16.83 \pm 2.52$ & $\begin{array}{l}\text { Gravels, tiny } \\
\text { debris, small } \\
\text { plastics, } \\
\text { broken } \\
\text { glasses, and } \\
\text { feathers }\end{array}$ \\
\hline Producer & 36 & $244 \pm 1.45$ & $12.67 \pm 1.98$ & $\begin{array}{l}\text { Gravels, tiny } \\
\text { debris, small } \\
\text { plastics, } \\
\text { shells, broken } \\
\text { glasses }\end{array}$ \\
\hline
\end{tabular}

Table 4 shows the physical hazard identified on dried anchovy samples. The most common physical hazard identified in all dried anchovy samples was stone or gravel, which accounted for 235 pieces $(77.05 \%)$. This discovery could be linked to the drying practices of local producers, as most of them used the traditional method of sun-drying the fish in an open area with a fine mesh net, which allowed for the introduction of potential physical hazards.

Table 4. The frequency and percentage of physical hazard identified on dried anchovy samples.

\begin{tabular}{|l|c|c|}
\hline $\begin{array}{l}\text { Physical Hazard } \\
\text { Identified }\end{array}$ & Frequency & Percentage \\
\hline Stone/gravel & 235 & 77.05 \\
\hline Tiny debris & 31 & 10.16 \\
\hline Small plastic & 23 & 7.54 \\
\hline Broken glasses & 4 & 1.31 \\
\hline Feather & 5 & 1.64 \\
\hline Shells & 7 & 2.30 \\
\hline Total & $\mathbf{3 0 5}$ & $\mathbf{1 0 0}$ \\
\hline
\end{tabular}

\section{RECOMMENDATION}

Good manufacturing and sanitation practices are considered a tool for ensuring the safety and quality of dried anchovy products, it is recommended that proper training on these practices be implemented to ensure that local dried anchovy producers and retailers in Marinduque are aware of the proper concept of food safety and quality. Finally, it is very important to innovate the existing technology on dried anchovy processing and be extended to possible adopters for them to improve the quality and safety of their products.

\section{CONCLUSIONS}

Three $(4.17 \%)$ of the 72 dried anchovy samples collected from local producers and retailers in Marinduque did not meet the histamine standard limit of $200 \mathrm{mg} / \mathrm{kg}$ set by the Philippine National Standard for Dried Anchovies, while 27 $(37.5 \%)$ had a histamine value greater than $500 \mathrm{mg} / \mathrm{kg}$, which is considered hazardous and unfit for human consumption. Physical hazards such as stone, small debris, shells, broken grasses, feathers, and small plastics were also identified, showing that good manufacturing and sanitation practices had not been followed.

\section{REFERENCES}

1. Amascual R., Irene E., Panganoron H., \& Pajarillo N. (2020). "Histamine profile of dried-salted fish sold in the local supermarket of Samar, Philippines". Italian Journal of Food Safety 2020; 9:8322.

2. AOAC Research Institute Validated: Certificate No. 070703. VERATOX for Histamine for the Quantitative Testing for Histamine for Mardak Global Export Inc.

3. Bureau of Agriculture and Fisheries Standards. (2016). Philippine National Standard: Dried anchovies (PNS/BAFS 176:2016). Quezon City, Philippines: Bureau of Agriculture and Fisheries Standards.

4. Bureau of Food and Drug-Philippine National Standard (BFAD-PNS). (2006). Ethnic food products Dried, salted fish Specifications. Manila: BFADPNS.

5. Food and Agriculture Organization/World Health Organization (FAO/WHO). (2012). Joint FAO/WHO Expert Meeting on the Public Health Risks of Histamine and Other Biogenic Amines from Fish and Fishery Products. Joint FAO/WHO expert meeting report. Rome: FAO Headquarters $1-111$.

6. Simora, R.M., Hilario, J.A., Peralta, E. M. \& Serrano, A.E. (2016). "Histamine content and quality assessment of dried salted sardines (Sardinella spp.) along the supply chain. Philippine”. Journal of National Science, 21-2, 31-39. 
7. Simora RC, Peralta EM, (2018). "Occurrence of Histamine and Histamine-forming Bacteria in Philippine Traditional Dried-salted Fish Products". Asian Fish Sci 311:73-88

8. Hungerford J.M. (2010). "Scombroid poisoning: A review". Toxicon 56, 231-243.

9. JASP, Team. (2020). JASP (Version 0.14.1).

10. Noche R, Mamaril AC, Dayrit MM, White ME, Roces MCR, Tayag EA, \& Abellanosa IP. (1998). "Scombroid fish poisoning outbreak in the Philippines". Philippine Journal of Ophthalmology 23-4, 170.

11. Olsen, A.R. (1998). "Regulatory action criteria for filth and other extraneous materials. Review of hard or sharp foreign objects as physical hazards in food." Regulatory Toxicology and Pharmacology 28:181-189.

12. Peralta E.M. (2003). "Changes in vacuum-packed smoked deboned milkfish stored at refrigeration temperature". Master's Thesis. Institute of Fish Processing Technology College of Fisheries and Ocean Sciences. University of the Philippines in the Visayas. Mioag-ao, Iloilo.

13. Prester L, (2011). "Biogenic amines in fish, fish products and shellfish: A review". Food Addit Contam 28:1547-60.

14. The Pharmaceutical Journal. (2009). Online: DOI:10.1211/PJ.2021.1.69388.

15. Villavicencio, W. (2018). "Histamine content of fermented fish products in Marinduque". Journal of Research and Innovation, 8-1, 1-4.

16. Visciano P, Schirone M, Tofalo R, Suzzi G, (2012). "Biogenic amines in raw and processed seafood". Front Microbiol 3:110

17. Zaman. M.Z., Bakar. F.A., Selamat. J. \& Bakar. J. (2010). "Occurrence of biogenic amines and amines degrading bacteria in fish sauce". Czech Journal Food Science, 28(5), 440-449. 